\title{
„Płatni mordercy"? Dyskurs budowania tożsamości zawodowej wśród pracowników deratyzacji
}

\author{
Gabriela Jarzębowska \\ Uniwersytet Warszawski
}

DOI: http://dx.doi.org/10.18778/1733-8069.16.4.10

Słowa kluczowe: szczury, deratyzacja, tożsamość zawodowa, analiza dyskursu, etyka

\begin{abstract}
Abstrakt: Niniejszy artykuł analizuje praktyki dyskursywne kształtujące tożsamość zawodową deratyzatorów (tępicieli gryzoni). Wywiady z pracownikami tej branży ukazują retorykę wytężonej pracy nad tożsamością. Stawiam tezę, że budowanie owej tożsamości lokuje się na dwóch poziomach. Pierwszy z nich (społeczny) wyznacza tożsamość budowaną w kontrze do percypowanego negatywnego odbioru społecznego. Drugi poziom (indywidualny) to praca „do wewnątrz”, obrazująca mierzenie się z etycznymi wyzwaniami związanymi z wykonywanym zawodem. Na podstawie przeprowadzonych wywiadów rozpoznaję cztery strategie racjonalizacji tępienia zwierząt. Owe dwa poziomy pracy nad tożsamością posiadają wspólny rdzeń, którym jest przekonanie o społecznej użyteczności pracy w deratyzacji.
\end{abstract}

Gabriela Jarzębowska, asystent badawczy na Wydziale Artes Liberales Uniwersytetu Warszawskiego, stypendystka Fundacji Fulbrighta na Wesleyan University i laureatka konkursu Preludium 14 Narodowego Centrum Nauki. Zajmuje się humanistyką środowiskową oraz studiami nad zwierzętami. Napisała doktorat Czystka gatunkowa. Tępienie szczurów jako praktyka kulturowa pod kierunkiem Profesora Andrzeja Elżanowskiego i Profesor Ewy Domańskiej.

\section{Adres kontaktowy: \\ Wydział Artes Liberales \\ Uniwersytet Warszawski \\ ul. Nowy Świat 69, 00-046 Warszawa \\ e-mail: gabriela.jarzebowska@al.uw.edu.pl}

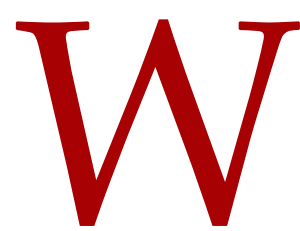
jednym z numerów „Biuletynu Polskiego Stowarzyszenia Pracowników Dezynfekcji, Dezynsekcji i Deratyzacji" przytoczona jest historia z życia deratyzatora. Pewnego razu, jadąc samochodem, został zatrzymany przez policję. Po wylegitymowaniu zapytano go o zawód, na co z kamienną twarzą odpowiedział: „Jestem płatnym mordercą". Konsternacja na twarzach policjantów ustąpiła miejsca śmiechowi po wyznaniu bohatera, że w rzeczywistości pracuje jako tępiciel szczurów (Bakuła 2012).

Przytoczony fragment stanowi znaczący przykład strategii narratywizacji obowiązków służbowych 
przez tępicieli gryzoni, ukazany w konwencji humorystyczno-anegdotycznej. Niniejszy artykuł jest próbą głębszego ujęcia tego zjawiska, które pozwoliłoby na uchwycenie mechanizmów dyskursywnych kształtujących tożsamość tej grupy zawodowej. Analizuję w nim strategie retoryczne związane z opisywaniem swojej pracy przez przedstawicieli profesji, której celem jest zwalczanie szkodników, a zatem takiej, którą za Everettem Hughesem i Collierem McMillanem określam mianem „brudnej roboty" (Hughes, McMillan 1958; por. też Hughes 1962). Stanowi on próbę zrozumienia narracji obrazujących i kształtujących praktyki społeczne, które z uwagi na konotacje z nieczystością i zdawaniem śmierci pozostają poza głównym nurtem debaty publicznej.

\section{Kontekst badania i inspiracje teoretyczne}

Niniejszy artykułpowstałw efekciebadańbędących częścią dysertacji doktorskiej, której przedmiotem są praktyki tępienia szczurów w Polsce po II wojnie światowej oraz organizujący je dyskurs. Prześledziłam w niej historyczne procesy formowania się współczesnej deratyzacji oraz jej podbudowy naukowej, analizując aksjologiczne uwarunkowania procesów decyzyjnych związanych z kontrolą populacji tego gatunku. Przeanalizowałam także towarzyszące jej praktyki dyskursywne, zwłaszcza to, $\mathrm{w}$ jakie klisze kulturowe wpisuje się retoryka uzasadniająca eksterminację miejskich gryzoni. Prowadzone badania opierają się na dwóch założeniach. Po pierwsze, że retoryka przedstawiania zwierząt poddawanych eliminacji posiada wyraźnie performatywny charakter, a więc nie tylko opisuje rzeczywistość społeczną, lecz także aktywnie ją współtworzy. Po drugie zaś, że wśród szeregu czynników kształtujących politykę tępienia szczurów za kluczowy należy uznać dyskurs tworzony przez branżę deratyzacyjną i współpracujących $\mathrm{z}$ nią ekspertów pest control. Stanowi on bowiem główny pas transmisyjny dla mediowania wiedzy naukowej do środków masowego przekazu, administracji publicznej i mieszkańców, wpływający na kształtowanie postaw i opinii dotyczących zarówno odczuwalnych zagrożeń związanych z obecnością szczurów w mieście, jak i tego, jakie czynniki należy uwzględniać przy podejmowaniu decyzji o metodach ich kontroli. Branżowy dyskurs DDD (dezynfekcja, dezynsekcja, deratyzacja) stanowi zatem główny przedmiot moich badań.

Kwestie relacji między ludźmi a innymi zwierzętami znajdują coraz szerszy oddźwięk w naukach społecznych, zaś socjologia, tradycyjnie skupiona na badaniu dynamiki społeczności ludzkich, coraz częściej włącza do swoich analiz relacje międzygatunkowe (Guillo 2015, por. też: Arluke, Sanders 1996; Franklin 1999; Peggs 2012), a nawet proponuje perspektywę nieantropocentryczną, w której zwierzęta z biernych przedmiotów ludzkich działań stają się pełnoprawnymi aktorami aktywnie współtworzącymi rzeczywistość społeczną (więcej na ten temat: Bucholc 2014). W kontekście niniejszych badań szczególnie istotne są analizy socjologów badających relacje międzygatunkowe w mieście, zwłaszcza dotyczące gatunków definiowanych jako problematyczne. Przykładu moga dostarczyć badania Colina Jerolmacka (2013) dotyczące społecznych postaw wobec gołębi oraz Tory Holmberg (2017) analizującej „politykę miejsca” (politics of place), określającą zasady wstępu do określonych przestrzeni dla przedstawicieli danego gatunku i populacji, co sama autorka określa „zooetnografia. Także w polskiej literaturze przedmiotu można dostrzec rosnące zainteresowanie tematyką zwierzęcą. Warto wspomnieć numer tematyczny "Qualitative Sociology Review" Animals and People 
z 2007 roku, poświęcony wyłącznie relacjom międzygatunkowym w ujęciu socjologicznym, a także coraz liczniejsze analizy polskich socjologów poświęcone relacjom między ludźmi a zwierzętami, szczególnie towarzyszącymi. Warto wymienić chociażby badania Krzysztofa Koneckiego (np. 2005; 2008) czy Hanny Mamzer (np. 2015; 2017).

Relacje między ludźmi a szczurami nie znalazły jednak do tej pory oddźwięku w naukach społecznych, chociaż nierzadko budzą zainteresowanie historyków i kulturoznawców (por. Hendrickson 1983; Sullivan 2005; Burt 2006). Tępienie szczurów, będące jedną z najbardziej rozpowszechnionych praktyk wobec zwierząt, należy zarazem do praktyk najbardziej stabuizowanych, niemal niefunkcjonujących w publicznych dyskusjach poświęconych relacjom między ludźmi a zwierzętami (a także w dyskusjach dotyczących kwestii dobrostanu i praw zwierząt). Retoryka obrazująca relacje człowieka z wolnożyjącymi szczurami w znaczącym stopniu oparta jest na lęku i wstręcie, zaś samo ich tępienie włączone zostało w dyskurs sanitarny i strategie zarządzania ryzykiem (Jarzębowska 2019).

Artykuł można sytuować w obrębie szeroko rozumianej analizy dyskursu, a więc działań zmierzających do zrozumienia „od wewnątrz” świata społecznego poprzez badanie sensów i form wypowiedzi tekstowych (Chiouliaraki 2008), przy czym tekst jest rozumiany szeroko, jako każdy obiekt lub czynność obdarzone społecznym znaczeniem. Dyskurs jest strukturą ograniczającą, ale także zasobem służącym jednostkom i zbiorowościom do wytwarzania rzeczywistości społecznej (Pawliszak, Rancew-Sikora 2012). W najogólniejszym znaczeniu celem niniejszego badania jest zatem analiza dyskursu opisującego codzienny świata życia deratyzatorów, ujmowany z perspektywy samych rozmówców, budujących i narratywizujących swoją tożsamość. Przedmiotem analizy są narracje rozumiane jako forma komunikowania, w ramach której narrator nadaje sens swoim działaniom oraz wydarzeniom, które mu się przydarzają. $\mathrm{W}$ opowieściach tożsamościowych narrator jest bowiem jednocześnie bohaterem wykorzystującym określone strategie komunikacji w celu kreowania własnej tożsamości (Dziob 2010). Może przy tym kreować ową tożsamość także w sposób pośredni, implicytny, a pewne treści mogą być niewyrażone $\mathrm{w}$ dosłownym odczytaniu tekstu. Bywa to dostrzegalne przede wszystkim $\mathrm{w}$ przypadku tematów kontrowersyjnych, celowo lub nieintencjonalnie pomijanych $\mathrm{w}$ dyskursie. Próbuję zatem także zwrócić uwagę na "ślepe plamki" przytaczanych narracji, a więc na to, co jest $w$ nich nieobecne. Idąc śladem Eviatara Zerubavela (2006), zakładam bowiem, że nie tylko procesy zauważania, ale i ignorowania określonych aspektów rzeczywistości mają głębokie podstawy społeczne i są związane $\mathrm{z}$ bardziej lub mniej uświadomionymi założeniami określającymi, co jest warte, a co niewarte dostrzegania.

Ze względu na ukierunkowanie niniejszej analizy na określone problemy bliskie jest mi rozumienie analizy dyskursywnej proponowanej przez Normana Fairclougha i jego problem-driven theory (Duszak, Fairclough 2008). Natomiast $\mathrm{z}$ uwagi na fakt, że analizując przytaczane wypowiedzi, szczególny nacisk kładę na język, istotnego kontekstu dla badań dostarcza także perspektywa socjolingwistyczna oraz związana z socjologią języka ${ }^{1}$. Ważnych inspiracji

\footnotetext{
${ }^{1}$ Zgodnie z tym, co pisze Stanisław Grabias (2003: 61), „Socjolingwistyka, konstruując model społecznych zachowań językowych, porusza się tylko w skali mikroprocesów i posługuje się przede wszystkim metodami wypracowanymi przez językoznawstwo. Natomiast socjologiczny opis językowej komunikacji dotyczy makrostruktur i przez to swoją perspek-
} 
dostarczyła ponadto teoria George'a Lakoffa i Marka Johnsona (2010), dotycząca roli metafor w życiu społecznym, głosząca, że są one nie tylko figurami retorycznymi, lecz także procesami mentalnymi, zarazem odzwierciedlającymi i kształtującymi społeczny odbiór świata.

Z uwagi na fakt, że niniejszej analizie przyświeca cel ukazania sposobów dyskursywizacji tożsamości zawodowej, istotnego kontekstu dla badania dostarcza teoria Anselma Straussa (2013). Podobne analizy są podejmowane także przez polskich badaczy, chociażby w monografiach wydawanych przez „Przegląd Socjologii Jakościowej” (Marciniak 2008; Bielski 2009; Miller 2010; Słowińska 2010). Zwłaszcza monografia Karoliny Słowińskiej, poświęcona analizie społecznego świata właścicieli gołębi pocztowych, stanowi istotny kontekst dla niniejszej analizy, z uwagi na opisywane w niej ludzko-zwierzęce interakcje.

Ponadto chociaż niniejsza analiza dotyczy retoryki używanej do tworzenia narracji tożsamościowych, blisko jej także do badań analizujących postawy (por. Czerwiński 2007; Piłat-Borcuch 2013) i emocje społeczne (Simlat-Żuk 2012; Konecki, Pawłowska 2013²), a z uwagi na jej etyczne zorientowanie, artykuł można także czytać w kontekście analiz dotyczących etyki zawodowej (Drzeżdżon 2013).

tywą badawczą i metodami ujmowania zjawisk zbliża się do socjologii historii, antropologii i etnografii". Z uwagi na wycinkowy charakter, mający jednak ambicję rozpoznania emocji społecznych definiujących stosunek do tzw. szkodników, niniejszą analizę można by sytuować na przecięciu tych subdyscyplin. Zgadzam się jednak z Katarzyną Leszczyńską i Katarzyną Skowronek (2010), postulującymi jeśli nie całkowite usunięcie różnic między nimi, to w każdym razie ich daleko posuniętą neutralizację, uznając różnice między nimi za mało istotne, zwłaszcza rozważane z perspektywy interdyscyplinarnej.

2 Por. też numer „Przeglądu Socjologii Jakościowej” poświęcony emocjom (2013, t. 9, nr 2).

\section{Metody i przebieg badań}

Podstawę empiryczną artykułu stanowią niestandaryzowane wywiady pogłębione z właścicielami i pracownikami firm DDD, a także, w ograniczonym stopniu, połączona $\mathrm{z}$ wywiadami obserwacja bezpośrednia. Koncentracja na narracjach i języku różni niniejszą analizę od wcześniejszego badania tej grupy społecznej (Himsworth i in. 2013), które skoncentrowane było przede wszystkim na pozyskiwaniu za pomocą wywiadów wiedzy eksperckiej dotyczącej szczurów i ich tępienia.

Wywiady przeprowadzałam od stycznia 2017 do maja 2018 roku, przy czym większość rozmów odbyła się w okresie od kwietnia do lipca 2017. W badaniu wzięło udział 21 osób z branży DDD z różnych miast Polski, zarówno dużych, jak i tych średniej wielkości. W grupie rozmówców znalazły się osoby prowadzące firmy jednoosobowe, szefowie małych firm rodzinnych oraz pracownicy jednego z kilku dużych przedsiębiorstw działających na terenie Polski (dwie osoby z kadry zarządzającej i dwie pracujące na szeregowych stanowiskach). Wśród moich rozmówców były osoby ze stażem pracy w branży DDD wahającym się od czterech do ponad 30 lat. Część z nich świadczy usługi zarówno dla klientów indywidualnych, jak i dla firm, inni zaś wyspecjalizowali się w oferowaniu stałej „opieki” w zakresie DDD obiektom objętym stałym monitoringiem antyszkodnikowym (np. zakłady przetwórstwa spożywczego). To rozróżnienie uważam za istotne, gdyż stała współpraca z przedsiębiorstwami charakteryzuje się nie tylko inną dynamiką pracy, lecz także wymusza konieczność dostosowania się do norm jakości wymaganych $\mathrm{w}$ przypadku danego obiektu. Łączy się to z określonymi procedurami i rozbudowaną biurokracją. Z kolei firmy pracujące $\mathrm{z}$ klientami indywidualnymi konfrontowane by- 
wają z emocjonalnymi reakcjami mieszkańców, na których posesji pojawił się szczur, co zazwyczaj wymaga podjęcia działań pozbycia się zwierzęcia „tu i teraz" wszelkimi dostępnymi środkami. Zakładam więc, że specyfika pracy z obydwoma typami klientów w znaczącym stopniu kształtuje działania podejmowane na rzecz pozbycia się tych zwierząt $\mathrm{z}$ danego terenu.

Dobór uczestników badania nastręczał pewnych trudności. Początkowo próbowałam dotrzeć do pracowników i właścicieli branży DDD, wysyłając e-maile z prośbą o uczestnictwo w badaniu - do 40 losowo wybranych firm z Warszawy i Łodzi zajmujących się tym rodzajem usług. Jednak jedynie 5 osób wyraziło zgodę na udział $\mathrm{w}$ badaniu. Do pozostałych uczestników badania dotarłam dzięki temu, że udało mi się nim zainteresować dwie wpływowe osoby z branży DDD (profesor SGGW oraz założyciel Muzeum DDD), które weszły w rolę „odźwiernych” (Hammersley, Atkinson 2000), udostępniając mi kontakty do dalszych rozmówców. Możliwość powołania się na wyżej wymienione osoby ułatwiła mi kontakt, tworząc efekt „kuli śniegowej" (zwłaszcza, że część rozmówców sama weszła w rolę "odźwiernych", udostępniając mi namiary na kolejne osoby). Efekt ten był łatwiejszy do uzyskania dzięki temu, że „odźwierni” byli najczęściej związani z Polskim Stowarzyszeniem Pracowników Dezynfekcji, Dezynsekcji i Deratyzacji (PSPDDD, ogólnopolska organizacja skupiająca firmy DDD), a tym samym dysponowali szerokimi kontaktami z osobami z tej branży z różnych miast Polski. W efekcie znaczna część moich rozmówców pochodziła z kręgu osób związanych lub sympatyzujących $\mathrm{z}$ tą organizacją. Namiary na dwóch rozmówców otrzymałam także od osoby z administracji publicznej, odpowiedzialnej za deratyzację w jednym z dużych miast na zachodzie Polski.
Poza jedną rozmówczynią wszyscy rozmówcy byli mężczyznami, najczęściej w przedziale wiekowym między 40 a 60 rokiem życia, choć zdarzały się i osoby młodsze. Mimo prób nie udało mi się dotrzeć do innych kobiet, stanowiących, jak udało mi się ustalić, znaczącą mniejszość $\mathrm{w}$ tej branży. Jeśli nawet współtworzą rodzinne firmy, zajmują się $\mathrm{w}$ nich zazwyczaj, jak to określiła jedna z kobiet (która nieskutecznie próbowałam namówić na rozmowę), „brudną robotą", przez co rozumiała obowiązki księgowo-finansowe.

Taki sposób doboru próby do badania pozwala podejrzewać, że mimo moich usilnych starań nie jest ona całkowicie reprezentatywna. Z uwagi na jakościowy charakter badania reprezentatywność próby rozumiem nie w znaczeniu statystycznym, ale związanym z tym, że bazuje na rozmowach z osobami, które są 1) wystarczająco otwarte i chętne do dzielenia się swoimi opiniami z nieznaną im osobą namawiającą je do udziału w badaniu i/lub 2) w bardziej (członkostwo) lub mniej (kontakty towarzyskie) sformalizowany sposób związane z PSPDDD. Nie można wykluczyć, że „milcząca większość” tych osób z branży, które nie wyraziły zainteresowania udziałem w badaniu, może mieć mniej refleksyjną postawę związaną z wykonywanymi obowiązkami służbowymi.

Kluczowym momentem w pozyskiwaniu rozmówców było moje uczestnictwo w targach ConExPest w maju 2017 roku, kiedy, znając już część osób z branży DDD, miałam możliwość poznania przez nich kolejnych uczestników badania. Możliwość spotkania w cztery oczy, w nieformalnej atmosferze, zwłaszcza w sytuacji bycia przedstawioną przez znajomych moich przyszłych rozmówców znacznie ułatwiała nawiązywanie kontaktu i skracała dystans. Efektem badania były inicjowane 
przeze mnie rozmowy z uczestnikami wydarzenia (pracownicy i właściciele firm DDD), na podstawie których sporządziłam notatki, a także dokumentacja fotograficzna. W efekcie prowadzenia rozmów $\mathrm{w}$ bardziej nieformalnej atmosferze, przy braku rejestracji dźwiękowej oraz nierzadko w obecności kilku osób biorących udział w dyskusji, możliwe było uzyskanie szerszej perspektywy zjawiska poprzez interakcje $\mathrm{z}$ badanymi $\mathrm{w}$ ich naturalnych, codziennych warunkach oraz obserwację ich wzajemnych interakcji.

Standardową procedurą, którą przyjęłam podczas zbierania wywiadów, była ich anonimizacja. Biorąc pod uwage rozmiar branży DDD w Polsce oraz łatwość rozpoznania uczestników badania, wyszłam bowiem z założenia, że anonimowość (o której każdorazowo informowałam rozmówców) może sprzyjać bardziej swobodnemu wyrażaniu przez nich opinii.

Z uwagi na ograniczenia związane $\mathrm{z}$ długością artykułu zawężam w nim problematykę badania, koncentrując się na wybranym aspekcie rozmów z deratyzatorami, jakim jest dyskursywizacja tożsamości zawodowej. $\mathrm{Z}$ tego samego powodu przytaczam i analizuje jedynie kilka fragmentów rozmów, które uznałam za szczególnie cenne poznawczo i/lub stanowiące egzemplifikację dominujących motywów i wątków. Stosowane wywiady niestandaryzowane zostały jedynie częściowo zogniskowane na interesujących mnie zagadnieniach. Nie zadawałam pytań odnoszących się bezpośrednio do opinii rozmówców, chyba że sami poruszyli dany wątek (na przykład pytanie o to, czy powinniśmy brać pod uwagę kwestię humanitarności stosowanych metod, pojawiało się wyłącznie wówczas, gdy rozmówca sam wspomniał, że stosowane metody są niehumanitarne, albo wyznawał, że ma dylematy moralne związane z wykonywaniem swoich obowiązków służbowych). Zdaję sobie sprawę, że nawet swobodny wywiad jest zawsze formą oficjalną (lub paraoficjalną) i nawet brak jawnego zogniskowania lub bezpośrednio zadawanych pytań zawsze skutkuje jakąś formą dyskursyfikacji zjawiska, które w innym przypadku, być może, nie miałoby możliwości ujścia, a tym samym - nie dostąpiłoby narratywizacji i otrzymania określonego znaczenia. Na podstawie rozmów z deratyzatora$\mathrm{mi}$, przysłuchiwania się ich rozmowom na targach, szkoleniach i w innych pół-formalnych sytuacjach, a także analizując zawartość branżowego Biuletynu PSPDDD, odniosłam jednak wrażenie, że owe typy dyskursyfikacji nie są rozdzielne - a więc że informacje, które otrzymywałam od rozmówców w czasie formalnych wywiadów rezonują (przynajmniej w znacznej części) z problemami, o których sami deratyzatorzy dzielą się ze sobą w swoim gronie. Oczywiście, wywiady badawcze nigdy nie będą stuprocentowym odbiciem dyskursu wewnątrzbranżowego - nie mam złudzeń, że są pewne tematy lub punkty widzenia, do których nie uzyskam wglądu jako osoba z zewnątrz. Dołożyłam jednak wszelkich starań, aby zebrane dane w największym możliwym stopniu odzwierciedlały punkty widzenia deratyzatorów, niekoniecznie stworzone ad hoc na potrzeby wywiadu.

\section{Deratyzatorzy wobec społeczeństwa}

Niniejszą analizę zacznę od tego, jak deratyzatorzy opisują społeczną percepcję swojego zawodu. W części analizowanych narracji wyraźnie dostrzegalny jest bowiem wątek związany z tym, jak osoby postronne reagują na pracę rozmówców oraz jakich postaw wobec pracy $\mathrm{w}$ deratyzacji może to ich zdaniem dowodzić. Jedna z rozmówczyń opowiada następującą historię: 
Jestem na wycieczce. Jakiejś tam zagranicznej. Niechcący się przyznałam. Widzę takie [robi minę wyrażającą zniesmaczenie - przyp. GJ]. Wręcz chyba nie podadzą mi ręki. Za pół roku jest telefon: „Pani X, pani jeszcze to robi?”. „No". „Jezu, jak dobrze! Niech pani przyjedzie, mam szczura, wyszedł z ubikacji!". Mówię: [głośno, z emfazą - przyp. GJ] „Teraz to jestem dobra? A pół roku temu to byłam be?". Ale jadę. Dopóki kogoś nie dotknie ten problem, to mówią, że jest „be". Ale jak go dotknie, to mówią: „Jezu, jak dobrze, że tacy ludzie istnieją!". [Rozmówca 11]

Wypowiedź posiada trójdzielny schemat. W pierwszej części narratorka opisuje nową sytuację społeczną, w której się znalazła (wycieczka) i negatywną reakcję innych wycieczkowiczów na informację o wykonywanym przez nią zawodzie. W środkowej części wypowiedzi następuje zwrot narracyjny: osoba wcześniej wyrażająca zniesmaczenie pracą rozmówczyni znajduje się w nowej sytuacji (szczur w toalecie), co skłania ją do zrewidowania wcześniejszej reakcji i skierowania się z prośbą o pomoc do narratorki. Trzecia część wypowiedzi stanowi komentarz będący próbą nadania znaczenia przywołanej historii: dopiero skonfrontowanie się z problemem obecności szczurów nadaje pracy szczurołapa właściwą jej rangę (,jak go dotknie, to mówią: «Jezu, jak dobrze, że tacy ludzie istnieją!»"). Opowieść bazuje zatem na schemacie odrzucenia („nie podadzą mi ręki”) i symbolicznego ponownego przyjęcia do społeczeństwa („Pani jeszcze to robi? [...] Jezu, jak dobrze!”). Zarazem tępienie szczurów opisywane jest za pomocą wyrażeń i konstrukcji językowych mogących znamionować wstydliwość czy wręcz tabuizację tego zawodu: „to robi" (na opisanie deratyzacji), „ten problem” (szczury), "tacy ludzie” (deratyzatorzy). Narratorka „niechcący się przyznała” do wykonywanej profesji, co może znamionować antycypację społecznej dezaprobaty. Należy podkreślić emocjonalny charakter wypowiedzi, wyrażany za pomocą środków pozawerbalnych: przywoływana reakcja rozmówców, wyrażana pełną dezaprobaty miną i głośno, emfatycznie wypowiadane pytania retoryczne. Może to znamionować strategię retoryczną dążącą do ukazania, z jednej strony, negatywnego statusu społecznego deratyzatora, z drugiej zaś - nadania tej profesji wyższej rangi poprzez podkreślenie jej społecznej przydatności. Użyte konstrukcje językowe („niechcący się przyznałam”, „,nie podadzą mi ręki”) ujawniają ponadto rozpoznaną przez rozmówczynię niechęć do zawodu szczurołapa, będącego czymś wstydliwym i niepożądanym. Została ona jednak zneutralizowana przez sytuację, w której znajoma z wycieczki znalazła się pół roku później (szczur w mieszkaniu), co z emfazą zaznacza rozmówczyni.

Nie jest to jedyna wypowiedź wyrażająca afirmatywny stosunek do wykonywanej pracy przy jednoczesnym wskazaniu jej społecznej kontrowersyjności. Podobne narracje pojawiały się $\mathrm{w}$ wielu wywiadach: deratyzacja jako praca ciekawa, dobrze płatna i pożyteczna, a zarazem nieciesząca się wystarczającym społecznym prestiżem. Symptomatyczna dla budowania narracji tożsamościowej tego zawodu jest poniższa wypowiedź:

No raczej nie traktują nas jak pracowników banku. (...) Na przykład jak zacząłem się tym zajmować, to wiele osób się śmiało. Ale w związku z tym jestem w lepszej życiowej sytuacji niż oni. Bo zajmuję się tym profesjonalnie. Jeśli to, co się robi, też się lubi i zaczyna się z tego odnosić jakieś korzyści... My też robiliśmy to nie tylko dla pieniędzy, ale też żeby komuś pomóc. Cieszy nas to, że możemy pomóc, to nie jest taka usługa jak z banku. [Rozmówca 7]

Następnie pojawia się dłuższa dygresja, w której narrator opowiada o swojej dawnej pracy w banku. 
Sprzedawał tam kredyty, także osobom pozbawionym zdolności kredytowej, z czym, jak wyznaje, miał etyczny dylemat. W kontekście poprzedniej pracy pełniony obecnie zawód deratyzatora jawi mu się jako pozytywna zmiana.

Ktoś ma problem. Przychodzimy, rozwiązujemy jego problem. To jest taki biznes win-win. Ja też po części wierzę w karmę, czyli że to, co dajemy, to dostajemy. Jakąś pozytywną energię zostawiamy. Staramy się tego klienta doinformować i zachować pozytywne relacje. Może powinno to być opisane w mediach, że ta praca jest potrzebna, że to jest normalne. Żeby szanować ten zawód. [Rozmówca 7]

Przytoczona wypowiedź jest istotna z kilku powodów. Po pierwsze, zwraca uwagę biznesowo-korporacyjny język, którym rozmówca opisuje swoją pracę („zajmuję się tym profesjonalnie”, „biznes win-win", „staramy się [...] klienta doinformować i zachować pozytywne relacje"). Stanowi to próbę ulokowania deratyzacji w kapitalistycznym imaginarium. Zarazem, podobnie jak we wcześniej cytowanej wypowiedzi, podkreślona jest społeczna użyteczność tej pracy (,cieszy nas to, że możemy pomóc”, „przychodzimy, rozwiązujemy jego problem") oraz wyrażone explicite dążenie do jej społecznej nobilitacji i szacunku (,powinno to być opisane w mediach, że ta praca jest potrzebna [...]. Żeby szanować ten zawód"). Po drugie, należy zwrócić uwagę, że w wypowiedzi konsekwentnie pomijane jest zabijanie zwierząt. Korporacyjny język zaciera ten wymiar pracy, w efekcie czego gryzonie stają się abstrakcyjnym, odcieleśnionym problemem do rozwiązania (swoją drogą podobny mechanizm narracyjny występuje także w poprzedniej wypowiedzi, zaburzony jest jednak obecnością szczura w toalecie, „ucieleśniającego” opisywane zjawisko). Obecne są natomiast pojęcia o duchowej proweniencji („karma”, „energia”), wpisujące tępienie zwierząt w domenę „pozytywnej energii”. Po trzecie, należy zwrócić uwagę na zabieg narracyjny polegający na zestawieniu figury deratyzatora i bankowca. Pod względem prestiżu społecznego zawody te są całkowicie nieprzystawalne: o ile pracownik banku cieszy się społeczną estymą, o tyle deratyzator traktowany bywa pogardliwie (,wiele osób się śmiało”). Z całości dłuższej wypowiedzi (której fragmenty przytoczono powyżej) można jednak wnioskować, że decyzja narratora o rezygnacji z pracy w banku na korzyść otwarcia firmy DDD uznawana jest $\mathrm{w}$ ramach tej wypowiedzi jako pozytywna nie tylko pod względem finansowym (,jestem w lepszej sytuacji życiowej niż oni”), ale także etycznym: żerującą na naiwności ludzi pracę bankowca uznaje za niemoralną, zaś tępienie szczurów to, z jego punktu widzenia, biznes typu „win-win”, którego celem jest nie tylko zysk, lecz także niesienie pomocy.

Inny rozmówca, który pracę w branży DDD zaczął jeszcze w latach 80., wspomina, że początkowo nie miał do niej serca i wykonywał ją wyłącznie dlatego, że dawała większe szanse na utrzymanie rodziny niż wyuczony zawód inżyniera. $Z$ czasem jednak jego stosunek do wykonywanej pracy zaczął się zmieniać.

Przychodzę drugi czy trzeci raz na ten sam obiekt, który robiłem wcześniej i raptem: „Panie, ależ pan tutaj zadziałał! Do tej pory jest spokój. Myślałem, że to się nie da". No i taka druga, trzecia opinia i człowiekowi się raptem zmienia nastawienie do tego, co robi, że jednak ludziom to służy, że są zadowoleni i tak z szacunkiem się odnoszą. (...) Zresztą moi panowie [pracownicy - przyp. GJ] to samo mówią. Zresztą ja mam też z drugiej strony odbiór, jak klienci się wyrażają o ich zaangażowaniu, pracy. Tak że jeżeli ktoś ma świadomość, że robi coś dobrze, że innym pasuje 
i to mówią, to wtedy naprawdę to może satysfakcję przynosić. [Rozmówca 13]

Ponownie pojawia się tu przekonanie o deratyzacji jako formie niesienia pomocy, co stanowi zrąb dla tworzenia zawodowej tożsamości. Praca $\mathrm{w}$ deratyzacji służy ludziom i w konsekwencji przynosi narratorowi satysfakcję. Nastawienie narratora do wykonywanej pracy, którą wcześniej traktował bez przekonania, zmieniła pozytywna reakcja klientów. Satysfakcja z pracy ma więc charakter relacyjny i pojawia się jako konsekwencja pozy tywnego oddźwięku, z jakim rozmówca i jego pracownicy spotykają się w efekcie wykonywanych obowiązków. Podobnie jak we wcześniejszej wypowiedzi pojawia się tu pojęcie szacunku, które można uznać za kluczowe w budowaniu afirmatywnej narracji tożsamościowej tej grupy zawodowej. Na podstawie przytoczonych wypowiedzi za zasadną można zatem przyjąć tezę, że retoryka tworzenia tożsamości zawodowej deratyzatora zasadza się przede wszystkim na tym właśnie pojęciu, a konkretnie na napięciu między dezaprobatą a szacunkiem ze strony osób postronnych. Kierując się teorią Straussa (2013), wskazującą na silnie interakcyjny charakter tożsamości, można zatem skonstatować, że tożsamość zawodowa wyłania się tu jako społeczny proces o charakterze symbolicznym, w którym jednostkowa tożsamość kształtowana jest w "zwierciadle” formułującego sądy społeczeństwa.

\section{Deratyzatorzy wobec szczurów}

Należy podkreślić, że nie wszystkie wypowiedzi znamionował afirmatywny stosunek do wykonywanych obowiązków. W niektórych z nich pojawiła się inna, bardziej negatywna narracja dotycząca pracy $\mathrm{w}$ deratyzacji. Zazwyczaj była ona związana $\mathrm{z}$ rozpoznaniem etycznej ambiwalencji tępienia zwierząt. Poniżej przytaczam wypowiedź, którą należy uznać za szczególnie wartościową poznawczo. Zawiera ona bowiem kilka (obecnych także $\mathrm{w}$ innych wypowiedziach) strategii retorycznych mających na celu rozmontowanie dysonansu poznawczego związanego z pracą w branży deratyzacyjnej.

ROZMÓWCA: To jest taka specyficzna praca. Nie każdy się decyduje. Ja bym się dzisiaj nie zdecydował. BADACZKA: Dlaczego?

ROZMÓWCA: Za dużo widziałem śmierci tych zwierząt, cierpienia, które im zadajemy. Tylko ja tutaj sobie sam na swój sposób tłumaczę, że to jednak jest $\mathrm{w}$ pewnym sensie obrona, więc mamy prawo, bo one się wdzierają na nasze terytorium. No ale też odreagowuję to, bo na przykład mięsa nie jem od lat. Tu zabijam, ale tu punkty zdobywam [śmiech]. (...) Trzeba mieć mocną psychikę, żeby się zajmować [deratyzacją - przyp. GJ]. Trudno się wyrwać z tego, (...) jak powiemy „nie", to nas zjedzą dłużnicy w pewnym momencie. Ale na pewno trzeba by było ludziom, którzy chcą się zajmować takim zawodem, są młodzi, uświadamiać, że z wiekiem świadomość człowieka się poszerza. I że być może zaczną mieć problem z mordowaniem w ten sposób, że się stworzenie przyklei, że się będzie męczyło, że zastosujemy drogę na skróty, żeby klient był bardziej zadowolony, szybciej nas polecił komuś. No trzeba być człowiekiem, sądzę, dosyć silnym psychicznie, żeby niszczyć inny gatunek. (...) Ciężko by mi było propagować ten zawód, mówiąc młodym ludziom, że jest wspaniały, że jest twórczy, że jest rozwijający. Rzemiosło jak każde inne, a satysfakcję przynoszące tylko o tyle, że czasami trzeba pokombinować, jak jakiś problem rozwiązać. Ale z tego nic nie zostaje. Domu nie zbudujemy, nie będziemy go podziwiać, nie stworzymy pięknej filiżanki. Tylko niszczymy, niszczymy... [Rozmówca 2] 
W wypowiedzi zwraca uwagę konstrukcja dyskursywna ustanawiająca zabijanie zwierząt jako czynność waloryzowaną negatywnie pod względem moralnym, a zarazem tworząca skomplikowany system jego racjonalizacji.

Z jednej strony narrator eksponuje niszczycielski wymiar swojej pracy i brak wymiernych efektów mogących przynieść satysfakcję wykraczającą poza poczucie doraźnego rozwiązania problemu. Podobnie jak $\mathrm{w}$ przytaczanym na wstępie artykule z Biuletynu PSPDDD, także tutaj pojawia się silnie nacechowane emocjonalnie (i tradycyjnie nieużywane w kontekście relacji międzygatunkowych) słowo „mordować” na opisanie zabijania szczurów. O ile jednak w tekście Bakuły słowo „morderca” funkcjonowało w obrębie stałego, ustalonego kulturowo związku frazeologicznego, posiadającego w tym kontekście przynajmniej częściowo wymiar humorystyczny, o tyle w analizowanym cytacie ma ono sens dosłowny, akcentujący emocjonalny wydźwięk wypowiedzi. Zarazem wypowiedź zestawia pracę przy tępieniu szczurów z innymi zawodami, których celem jest wytwarzanie dóbr (architektura, projektowanie przedmiotów codziennego użytku), na zasadzie antytezy tworzenie/ niszczenie. Wytwarzanie dóbr, które możemy później podziwiać, kontrastuje zatem z zadawaniem śmierci, które wedle tej narracji jest wyłącznie destrukcją. Deratyzacja jest zatem negatywnie waloryzowana z dwóch powodów. Po pierwsze, dlatego że łączy się z zadawaniem cierpienia czującym istotom. Po drugie zaś, dlatego że jest aktem destrukcji, a nie tworzenia. Można jednak odnieść wrażenie, że te dwa wymiary łączą się tu ze sobą, czego zdaje się dowodzić stwierdzenie „trzeba być (...) człowiekiem dość silnym psychicznie, żeby niszczyć inny gatunek".

Z drugiej strony zawarta w wypowiedzi konstrukcja dyskursywna zawiera system moralnych umo- tywowań zabijania zwierząt, które mogą stanowić echo technik „,neutralizacji” przyjmowanych przez osoby naruszające porządek społeczny (Sykes, Matza 1957). Na podstawowym poziomie działania te sa motywowane względami osobistymi, związanymi z faktem, że dla narratora są one źródłem utrzymania, które na etapie życia, na jakim się znajduje, trudno zmienić na inne („Trudno się wyrwać z tego, (...) jak powiemy «nie», to nas zjedzą dłużnicy”). Ów osobisty aspekt uprawomocniania swoich działań jest zarazem silnie ulokowany w sferze społecznej. Fragment „zastosujemy drogę na skróty, żeby klient był bardziej zadowolony" odnosi się do powszechnej praktyki stosowania szybkich i skutecznych, ale uznawanych za najbardziej niehumanitarne (Mason, Littin 2003) pułapek lepowych. Fragment ten można czytać jako wyrażone implicite przekonanie o moralnej współodpowiedzialności klienta za brutalne metody deratyzacji, związane ze zjawiskiem delegowania „brudnej roboty” (Hughes 1962).

Równocześnie zabijanie szczurów zostało umotywowane nie tylko na poziomie społecznym, ale także międzygatunkowym. Jest ono potraktowane jako obrona ludzi przed zwierzętami „wdzierającymi się na nasze terytorium”. Relacja szczur-człowiek została zatem ukazana jako międzygatunkowy konflikt, w ramach którego obowiązujące zasady moralne zostają zawieszone.

Owe dwa poziomy wyjaśnień korespondują z rozróżnieniem na wymówkę (excuse) i usprawiedliwienie (justification), zaproponowanymi przez Marvina Scotta i Stanforda Lymana (1968). Wymówka to wyjaśnienie uznające wykonany czyn za moralnie nieuprawniony, ale odmawiające przyznania pełni odpowiedzialności za jego dokonanie. W przypadku cytowanej wypowiedzi odpowiedzialność zostaje oddelegowana na innych aktorów społecznych, 
bezpośrednio (klienci) lub pośrednio („dłużnicy”) zaangażowanych $\mathrm{w}$ podejmowanie przez narratora decyzji moralnej. Natomiast usprawiedliwienie zakłada przyznanie odpowiedzialności za dokonany czyn przy jednoczesnym zakwestionowaniu jego niemoralności. $\mathrm{W}$ tym przypadku będzie to narracja definiująca deratyzację jako obronę przed niebezpiecznymi zwierzętami.

Zawarty w wypowiedzi system wymówek i usprawiedliwień jest jednak wyraźnie chwiejny. Osłabia go użycie sformułowań i konstrukcji językowych mogących sugerować wątpliwości co do używanych uprawomocnień (,,ja tutaj sobie sam na swój sposób tłumaczę", „w pewnym sensie obrona"). Co więcej, uzupełnia go trzecia strategia narracyjna uprawomocniająca wykonywanie obowiązków służbowych. Jest nim nawiązanie rozmówcy do jego wegetarianizmu. Nie posiada ona ani cech wymówki (bo narrator przyznaje sobie odpowiedzialność za dokonywane czyny), ani usprawiedliwienia (bo ustanawia zabijanie szczurów jako działanie niemoralne). Deklaracja powstrzymywania się od jedzenia mięsa jest określana mianem „odreagowania”, co rezonuje z psychologizującą narracją używaną w innych częściach wypowiedzi (,trzeba być człowiekiem [...] silnym psychicznie”, "trzeba mieć mocną psychikę", ,z czasem świadomość człowieka się poszerza”). Jednak zdanie „tu zabijam, ale tu punkty zdobywam" może także znamionować dążenie do moralnego zadośćuczynienia w związku z pracą w branży ukazywanej w wypowiedzi jako ambiwalentna etycznie. Tak skonstruowana argumentacja pozwala narratorowi "zachować twarz" przy jednoczesnym podważeniu moralności wykonywanych obowiązków służbowych.

Poniższy fragment uświadamia, że sposób etycznego uprawomocniania tępienia szczurów może także przebiegać wzdłuż zupełnie innych wektorów. Aby zrozumieć zawarty $\mathrm{w}$ wypowiedzi mechanizm dyskursywny, konieczne jest przytoczenie obszerniejszych fragmentów rozmowy:

ROZMÓWCA: Powiem pani jako ciekawostkę: 32 lata prowadzę działalność gospodarczą w tym zakresie. Nie potrafię pani powiedzieć, ile tych gryzoni wytępiłem, natomiast nie zabiłem ani jednego gryzonia. Ja osobiście nie zabiłem. Ja nie zabiłem karpia, nie zabiłem kury, królika, nie zabiłem nic. Nie zabijam. Dlatego, że tępię gryzonie. Ale o efektach tego tępienia to mi klienci mówią. Ja tylko dobieram odpowiednie trutki, żeby je wytępić. (...) Ja mogę tą pułapkę lepową z tą myszką wynieść, sprzątnąć, zutylizować.

BADACZKA: Ale co się z nią dzieje? No bo trzeba ją dobić?

ROZMÓWCA: Nie. Ona zdycha powoli. Najlepiej zapakować w worek foliowy i wynieść do pojemnika na śmieci. Ona się już nie uwolni. Ona tam zdechnie w tym pojemniku. Później ją wywiozą na pryzmę śmieci, za miasto, gdzie jest śmietnisko, i tam będzie dochodzić do siebie. Ona będzie cały czas cierpiała. No ale jak my się zaczniemy litować nad gryzoniami, proszę panią, to proszę mi powiedzieć, jakby pani teraz podeszła, że na przykład w pułapkę zatrzaskową wpadnie łapa szczura, on piszczy strasznie głośno, i co by pani zrobiła?

BADACZKA: Trzeba jakoś dobić.

ROZMÓWCA: Ale ja jeszcze raz powtarzam, ja nie zabiłem w życiu żadnego stworzenia. I nie zabiję.

BADACZKA: A dlaczego?

ROZMÓWCA: Nie wiem. Jestem miękki. Jestem miękki chłop. Nie zabiję niczego. Muchę tylko ewentualnie, jak mi dokucza. Natomiast żadnego stworzenia w życiu nie zabiłem. Do zabicia kury sąsiada wołała moja żona, karpie kazała w sklepie ubijać. Ja nie zabiję. Po prostu nie zabiję. Tak zostałem wychowany. I moi bracia też. Nie zrobimy żadnemu zwierzęciu 
krzywdy. Jako dziecko jeździłem na wakacje do moich dziadków. I widziałem raz w życiu, gdzie dziadek kazał mi wyjść, a ja mimo tego stałem w progu, widziałem jak podrzynał gardło owcy. Jak tą krew do jakiejś miski, pojemnika zbierał. Ja się rozryczałem, pamiętam, że babcia z ciocią nie mogły mnie uspokoić, że ja chciałem do domu wracać, a ja już miałem 7 czy 8 lat. I od tamtego czasu został mi uraz. Nie zabiję żadnego stworzenia, nie zrobię krzywdy człowiekowi. A wręcz odwrotnie - wolę pomagać, niż robić krzywdę. Tak zostałem wychowany, przepraszam. Ja się już nie zmienię. (...) I nawet nieraz pracownik mówi: „O, szczur leci koło pana!” Niech se leci. I tak przyjdzie do tej trutki. Ja go nie będę niczym zabijał. Ja mu podaję atrakcyjne jedzenie. On przyjdzie, zje i, i tak odejdzie do Bozi, i tak odejdzie do Bozi. To po co? To jest kwestia czasu tylko. (...) Koegzystuję jakby z nimi. One czekają, aż ja im podam jedzenie, ja wychodzę, one jedzą, wszystko jest fajnie, wszystko w porządku. [Rozmówca 14]

W przytoczonych fragmentach wypowiedzi zwraca uwagę kilka kwestii. Po pierwsze, wyraźnie obecne są $\mathrm{w}$ nich tępione gryzonie - i to nie (lub nie tylko) jako problem do rozwiązania, ale jako żyjące, pobierające pokarm, cierpiące i konające zwierzęta, do pewnego stopnia posiadające podmiotowość („,czekają, aż ja im podam jedzenie”, "będzie cały czas cierpiała”, ,piszczy strasznie głośno”, ,przyjdzie, zje i, i tak odejdzie do Bozi, i tak odejdzie do Bozi"). Podkreślona jest zatem fizyczność, namacalność praktyk deratyzacyjnych, które przestają być czymś abstrakcyjnym i odcieleśnionym.

Po drugie, tożsamość deratyzatora wyłaniająca się z tej narracji jest głęboko zakorzeniona w relacjach. O ile jednak w przytaczanych wcześniej wypowiedziach owa relacyjność dotyczyła kontaktów międzyludzkich (głównie relacji z klientami), o tyle niniejsza historia podkreśla relacje narratora ze szczurami. Są one portretowane jako harmonijne, bazujące na wzajemnej wymianie („Koegzystuję jakby z nimi. One czekają, aż ja im podam jedzenie, ja wychodzę, one jedzą, wszystko jest fajnie, wszystko w porządku"). Między tymi dwiema sferami dosadnymi opisami konania zwierząt i harmonijnej koegzystencji z nimi - występuje wyraźne napięcie. Zarazem jednak wyeksponowana brutalność praktyk stanowi paradoksalny przejaw relacyjności, co stawia tę narrację w kontrze do wypowiedzi sięgających do odcieleśnionego języka biznesowo-korporacyjnego.

Po trzecie, w wypowiedzi można zaobserwować dwa ważne przesunięcia pojęciowe. $Z$ jednej strony deratyzacja zostaje oddzielona od zabijania. O ile zabijanie innych zwierząt (w tym przypadku - zarzynanej owcy) opisywane jest w sposób znamionujący zaangażowanie emocjonalne narratora (,ja się rozryczałem”, „został mi uraz”), o tyle dla tępienia szczurów używane są inne konstrukcje językowe czasem utarte („efekty tępienia”, „zdycha”), czasem zaś osobliwe („dochodzić do siebie”, „odejdzie do Bozi"). Z drugiej zaś strony dobijanie zostaje zrównane $\mathrm{z}$ zabijaniem, nawet $\mathrm{w}$ przypadku działania mającego na celu skrócenie skrajnego cierpienia. Rozmówca deklaruje, że nigdy nie robi krzywdy żadnemu zwierzęciu, przy czym krzywda ta jest rozumiana specyficznie - jest nią dobicie cierpiącego zwierzęcia, ale już nie jego trucie. Rozmówca wyraźnie odróżnia zatem „zabijanie”, a więc fizyczną likwidację zwierzęcia własnym rękami („osobiście”), od ich zwalczania, polegającego na truciu i łapaniu na pułapki lepowe (,Ja go nie będę niczym zabijał. Ja mu podaję atrakcyjne jedzenie"). Według tej narracji obecność technologicznego nie ludzkiego aktora w postaci rodentycydu lub pułapki, pośredniczącego między deratyzatorem a tępionym przez niego 
zwierzęciem, zdejmuje moralną odpowiedzialność z tego pierwszego. Zabijanie szczurów funkcjonuje tutaj w ramach całkowicie innej „matrycy postrzegania" niż zabijanie zwierząt gospodarskich, choć zarazem wyłamuje się z binarnego podziału na matrycę antropomorficzną i animalistyczną (Konecki 2005 57). Postrzegając szczury w kategoriach animalistycznych, narrator podkreśla zarazem szczególny charakter relacji z nimi, oparty na szczególnie rozumianej koegzystencji i harmonii.

Efektem tak skonstruowanej narracji jest neutralizacja dysonansu poznawczego poprzez ukazanie wewnętrznie spójnej, prawej jednostki. W przeciwieństwie do wcześniej przytaczanych wypowiedzi nie znajdujemy tutaj ani mechanizmu usprawiedliwiania, ani stosowania wymówek, nie ma także zastosowanej przez rozmówcę 2 strategii „zadośćuczynienia". Aby zaprezentować się jako jednostka integralna moralnie, narrator stosuje natomiast konstrukcję dyskursywną opierającą się na logice, zgodnie z którą tępienie szczurów nie jest zabijaniem. Mechanizm ten jest szczególnie wartościowy poznawczo w kontekście przywołanej historii z dzieciństwa, a mianowicie wstrząsu na widok zabijanej owcy. Narrator zaznacza, że owa wrażliwość na ludzkie i pozaludzkie cierpienie została mu do dziś: nie zabija nawet kury, bo jest „miękki chłop”. Wyraźne i dobitne podkreślanie swojej wrażliwości, prawości i dobroci ma na celu stworzenie wizji jednostki głęboko moralnej i brzydzącej się przemocą.

Tak skonstruowana narracja pozwala na ukazywanie konsekwentnie afirmatywnej wizji swojej pracy mimo wyeksponowania jej brutalności. Owa afirmacja zasadza się jednak na innej płaszczyźnie niż w przypadku wcześniejszych wypowiedzi. Tam wynikała z przekonania o społecznej przydatności pracy, zaś szczury albo nie pojawiały się wcale, albo tylko mimochodem (szczur wychodzący z toalety w wypowiedzi rozmówcy 11). Natomiast w niniejszej wypowiedzi społeczna użyteczność deratyzatora, chociaż implicite zawarta $\mathrm{w}$ wypowiedzi, nie jest sednem ukazywanego $\mathrm{w}$ jej ramach zawodowego etosu. Jest nim natomiast to, co w innym wypowiedziach było albo pomijane, albo ukazywane w ramach systemu uprawomocnień - a mianowicie jego relacje z tępionymi zwierzętami. Narrator nie potrzebuje ani usprawiedliwień, ani wymówek, ponieważ $\mathrm{w}$ ramach wyznawanej przez niego etyki zwalczanie gryzoni nie jest zabijaniem - a nie będąc nim, zostaje usunięte z obszaru działań wątpliwych moralnie.

\section{Konkluzja}

Dominujące wśród deratyzatorów wypowiedzi świadczą o zrozumieniu swojej roli jako dostarczycieli społecznie pożytecznej, choć moralnie ambiwalentnej usługi. Przeważają opinie o deratyzacji jako działalności ważnej i koniecznej, choć zazwyczaj niecieszącej się wystarczającym prestiżem społecznym. Zarazem część rozmówców wyraża jawne obiekcje moralne związane $\mathrm{z}$ wykonywanym przez siebie zawodem. Nie spotkałam ani jednej osoby, która deklarowałaby, że pozbawianie zwierząt życia przynosi jej przyjemność, ani takiej, która podważałaby zdolność szczurów do odczuwania cierpienia. Zarazem jednak należy podkreślić różnorodność postaw w ramach przebadanej grupy. Spotkałam się zarówno z osobami wykazującymi silne obiekcje natury moralnej wobec wykonywanej pracy (w tym jedna osoba przyznająca wprost, że z tego względu nie chciałaby dłużej jej wykonywać), jak i takimi, które sprawiały wrażenie pozbawionych podobnych refleksji, eksponując wyłącznie zagrożenia generowane przez szczury i konieczność obrony przed nimi. Można jednak zaryzykować uogólnie- 
nie, że zabijanie gryzoni traktowane jest w przytoczonych narracjach w kategoriach mniejszego zła, będącego efektem wyższej konieczności - nieprzyjemnej, lecz niezbędnej.

W wypowiedziach dominuje retoryka wytężonej pracy nad tożsamością zawodową, której dokonują rozmówcy. Budowanie owej tożsamości (na podstawie niektórych wypowiedzi można by wręcz zaryzykować stwierdzenie: etosu) deratyzatora lokuje się na dwóch poziomach.

Pierwszy poziom wyznacza tożsamość budowana $\mathrm{w}$ kontrze do percypowanego negatywnego odbioru społecznego. Warto w tym kontekście odwołać się do rozważań o tożsamościowym wymiarze wykonywanego zawodu wspomnianego wcześniej Hughesa. Autor zwraca uwage na społeczny wymiar funkcjonowania „brudnych” profesji, których wykonawców można określić mianem agentów oddelegowanych przez społeczeństwo do wykonywania aktywności niechcianych, wstydliwych, ale zarazem powszechnie uznawanych za społecznie potrzebne (Hughes 1962). Owe kontrowersje są szczególnie wyraźne w branży DDD, kojarzonej z tym, co negatywnie nacechowane kulturowo, z nieczystością i zabijaniem. Nie zmienia to faktu, że z usług deratyzatorów korzysta się chętnie, kiedy tylko na terenie posesji pojawia się niechciany gryzoń. W analizowanych wypowiedziach można zauważyć pośrednie lub bezpośrednie odniesienia do tak rozumianej hipokryzji związanej ze społeczną percepcją tego zawodu. W ramach tej modalności praca nad tożsamością oscyluje wokół dwóch przeciwstawnych pojęć: dezaprobaty i szacunku. Większość przytoczonych narracji celuje w przełamanie otaczającej pracę deratyzatora dezaprobaty i uzyskanie szacunku potencjalnych klientów oraz osób postronnych, przy jednoczesnym dążeniu do uznania społecznej wagi wykonywanej profesji. Ten aspekt pracy nad tożsamością to zatem praca „na zewnątrz”, dążąca do zbudowania afirmatywnego wyobrażenia pracownika deratyzacji w społecznym imaginarium.

Z drugiej strony przytoczone narracje wskazują także na tożsamościową pracę „do wewnątrz”, obrazującą mierzenie się z etycznymi wyzwaniami związanymi z wykonywanym zawodem. Na podstawie przeprowadzonych wywiadów można rozpoznać cztery strategie narratywizacji tępienia zwierząt, których celem jest etyczne umotywowanie wykonywania profesji. Pierwsza z nich to 1) wymówka, a więc strategia odmawiająca przyjęcia pełni odpowiedzialności za wykonywane działania. W ramach tak skonstruowanej argumentacji deratyzator wprawdzie wykonuje pracę wątpliwą moralnie, ale tylko dlatego, że jest do tego delegowany przez społeczeństwo (co rezonuje z mechanizmem „brudnej roboty"). Druga strategia to 2) usprawiedliwienie. W jej ramach narrator uznaje wprawdzie odpowiedzialność za dokonywane czyny, jednak motywuje je wyższą koniecznością, jaką jest problem obecności szczurów w otoczeniu człowieka. Te dwa sposoby argumentacji pojawiały się (razem lub rozłącznie) w większości przeprowadzonych rozmów. W pojedynczych przypadkach występowały jednak także dwie inne strategie radzenia sobie $z$ moralną ambiwalencją zwalczania gryzoni. Były to 3) „zadośćuczynienie”, a więc wzięcie odpowiedzialności za nieetyczne (zdaniem narratora) działania przy jednoczesnej strategii „,moralnego offsetu”, polegającego na powstrzymaniu się od jedzenia mięsa, oraz 4) zaprzeczenie, w ramach którego tępienie szczurów zostało symbolicznie odłączone od zabijania.

W przytoczonych narracjach te dwa typy pracy tożsamościowej - zewnętrzna (społeczna) i wewnętrz- 
na (psychologiczno-etyczna) - zazwyczaj występują rozdzielnie, nie wchodząc ze sobą $\mathrm{w}$ dialog. Zasadne jest jednak przyjęcie tezy, że posiadają one wspólny rdzeń, którym jest przekonanie o społecznej użyteczności pracy w deratyzacji - użyteczności mającej przekraczać ograniczenia społecznej dezaprobaty z jednej i etycznych ambiwalencji z drugiej strony. Skłaniam się zarazem do interpretacji, że deklaracje o społecznej użyteczności wykonywanej pracy mogą posiadać także funkcję kompensacyjną. Wykonywanie zawodu polegającego na zadawaniu śmierci łączy się bowiem z koniecznością wpisania się w określony skrypt kulturowy. Podkreślenie społecznej przydatności wykonywanych obowiązków może być dla tępicieli szczurów najłatwiej osiągalną alternatywą wobec realizacji skryptu cynika, zabijającego zwierzęta wyłącznie dla zysku. Jeśli ta intuicja jest słuszna, model „użyteczności” w narracji o deratyzacji byłby rodzajem buforu bezpieczeństwa, chroniącego przed popadnięciem w kulturowy stereotyp „płatnego mordercy”. Skłaniam się ku tej interpretacji także dlatego, że w wielu wywiadach deklaracje o przydatności wykonywanej pracy występowały $\mathrm{w}$ bezpośrednim sąsiedztwie wyrażanych wątpliwości natury etycznej. Sprawiało to wrażenie, jakby rozmówcy chcieli usprawiedliwić swoje kontrowersyjne etycznie działania, zastrzegając, że nawet jeśli zabijanie zwierząt nie jest moralnie neutralne, to stanowi rodzaj „mniejszego zła”, które $\mathrm{w}$ ostatecznym rozrachunku należy postrzegać pozytywnie. Tożsamość deratyzatora to zatem tożsamość dynamiczna, wyłaniająca się w efekcie starcia z dwoma sferami - zewnętrzną (dezaprobata społeczna) i wewnętrzną (rozpoznanie etycznych ambiwalencji wykonywanych działań). Wyłanianie owej tożsamości jest efektem pracy przy przełamywaniu tych podwójnych ograniczeń za pomocą określonych konstrukcji dyskursywnych podkreślających społeczną przydatność wykonywanego zawodu.
Jako ostatni wniosek wypływający z przeprowadzonej analizy wypada wskazać to, że retoryka tożsamości $\mathrm{w}$ deratyzacji ma charakter silnie relacyjny. Jest on wyraźnie związany z reakcją osób postronnych na wykonywane obowiązki i koncentruje się na wspomnianym wcześniej zjawisku obecności lub nieobecności szacunku. Podkreślając społeczną użyteczność wykonywanych obowiązków służbowych, narratorzy rozpoznają niedostateczne docenienie owej użyteczności ze strony innych członków społeczeństwa. Wbrew popularnym wyobrażeniom (utrwalonym m.in. przez film „Szczurołap" Andrzeja Czarneckiego) przekazy o tworzeniu znaczących relacji deratyzatorów ze zwierzętami są jednak $w$ analizowanych wywiadach marginalne i, poza rozmówcą 14, prawie zawsze ograniczone do konieczności dobicia zwierzęcia złapanego w pułapkę lepową ${ }^{3}$. W większości wypowiedzi dominuje narracja traktująca tępienie szczurów jako problem do rozwiązania. Choć zatem etyczne ambiwalencje związane $z$ deratyzacją są zazwyczaj rozpoznane, $\mathrm{w}$ analizowanych narracjach rzadko pojawiają się dłuższe opisy mogące znamionować obecność znaczącej (choć bazującej na przemocy) relacji ze zwalczanymi gryzoniami. Przytoczone wywiady ujawniają zatem tożsamość deratyzatorów jako tożsamość dynamiczną, budowaną w reakcji na społeczne i etyczne kontrowersje związane z pracą w deratyzacji (a zazwyczaj także w kontrze do nich). Ostateczną odpowiedź na pytanie o istotę relacji między tymi dwiema sferami mogłoby przynieść badanie analizujące społeczne postawy wobec tępicieli szczurów wśród osób nienależących do branży DDD. Mogłoby ono ustalić, co stanowi główny rdzeń społecznych kontrowersji

\footnotetext{
${ }^{3}$ Może być to spowodowane specyfiką współcześnie stosowanych rodentycydów, niewymagających wcześniejszego skarmiania, a tym samym - wielokrotnego przychodzenia deratyzatora na tan sam obiekt.
} 
wobec deratyzatorów: czy jest to w przeważającej mierze sprzeciw natury etycznej (zabijanie zwierząt jako działanie niemoralne), czy estetycznej (szczur jako zwierzę generujące negatywne skojarzenia kulturowe).

\section{Bibliografia}

Arluke Arnold, Sanders Clinton (1996) Regarding animals. Animals, culture and society. Philadelphia: Temple University Press.

Bakuła Tadeusz (2012) Jestem płatnym morderca. „Biuletyn Polskiego Stowarzyszenia Pracowników Dezynfekcji, Dezynsekcji i Deratyzacji", t. 1, nr 68, s. 43-46.

Bielski Piotr (2009) Rolnictwo ekologiczne jako zawód i powołanie. Studium tożsamości, organizacji i potencjału rozwojowego polskich rolników ekologicznych. „Przegląd Socjologii Jakościowej”, t. 5, nr 3.

Bucholc Marta (2014) Wprowadzenie. O trwałości antropocentryzmu i paradoksach postantropocentrycznych w naukach społecznych [w:] Roman Chymkowski, Anna Jaroszuk, red., Ludzie i zwierzęta. Warszawa: Wydawnictwo Uniwersytetu Warszawskiego, s. 15-33.

Burt Jonathan (2006) Szczur. Przełożył Andrzej Leśniak. Kraków: Universitas.

Chiouliaraki Lilie (2008) Discourse analysis [w:] Tony Bennett, John Frow, eds., The SAGE handbook of cultural analysis. London: SAGE, s. 674-698.

Czerwiński Kazimierz (2007) Metodologiczne aspekty pomiaru postaw jako wypadkowej systemu wartości [w:] Wojciech Maliszewski, red., Komunikacja społeczna a wartości w edukacji. Nowe znaczenie i sytuacje, T. 1: Humanistyczne (i inne) konteksty komunikowania "się" $i$ "Ja" w obszarze wartości wewnatrz edukacji. Toruń: Wydawnictwo Adam Marszałek, s. 222-236.

Drzeżdżon Wojciech (2013) Etyczne aspekty pracy zawodowej. Wybrane zagadnienia. „Studia Gdańskie. Wizje i rzeczywistość”, t. 10 , s. 21-35.

Duszak Anna, Fairclough Norman, red. (2008) Krytyczna analiza dyskursu. Interdyscyplinarne podejście do komunikacji społecznej. Kraków: Universitas.
Projekt „Czystka gatunkowa. Polityczny wymiar tępienia szczurów po 1945 roku" został sfinansowany przez Narodowe Centrum Nauki w ramach konkursu Preludium, na postawie wniosku 2017/27/N/ HS3/00013.

Dziob, Agnieszka (2010) Badanie narracji - między psychologia, socjologia a językoznawstwem. „Kwartalnik Językoznawczy”, t. 2, s. 1-9.

Franklin Andrian (1999) Animals and modern cultures: A sociology of human-animal relations in modernity. London, Thousand Oaks, New Delhi: SAGE.

Grabias Stanisław (2003) Język w zachowaniach społecznych. Lublin: Wydawnictwo UMCS. Guillo Dominique (2015) What is the place of animals in the social sciences? The limits to the recent rehabilitation of animal agency. "Revue Française de Sociologie”, t. 56 , no. 1 , s. $116-141$.

Hammersley Martyn, Atkinson Paul (2000) Metody badań terenowych. Przełożył Sławomir Dymczyk. Poznań: Zysk i Spółka.

Hendrickson Robert (1983) More cunning than men. A social history of rats and men. New York: Kensington. Himsworth Chelsea i in. (2013) Using experiential knowledge to understand urban rat ecology: A survey of Canadian pest control professionals. „Urban Ecosystems”, vol. 16, s. 341-350.

Holmberg Tora (2017) Urban animals. Crowding in zoocities. London, New York: Routledge.

Hughes Everett (1962) Good people and dirty work. "Social Problems", vol. 10, no. 1, s. 3-11.

Hughes Everett, McMillan Collier (1958) Men and their work. Toronto: Canada, Ltd.

Jarzębowska Gabriela (2019) Czystka gatunkowa. Tępienie szczurów jako praktyka kulturowa. Praca doktorska napisana pod kierunkiem Ewy Domańskiej i Andrzeja Elżanowskiego na Wydziale Artes Liberales Universytetu Warszawskiego. 
Jerolmack Colin (2013) The global pigeon. Chicago, London: The University of Chicago Press.

Konecki Krzysztof (2005) Ludzie i ich zwierzęta. Interakcjonistyczno-symboliczna analiza społecznego świata właścicieli zwierząt domowych. Warszawa: Scholar.

Konecki Krzysztof (2008) Touching and gesture exchange as an element of emotional bond construction. Application of visual sociology in the research on interaction between humans and animals. „Forum Qualitative Sozialforschung / Forum: Qualitative Social Research", vol. 9, no. 3, Art. 33.

Konecki Krzysztof, Pawłowska Beata (2013) W stronę socjologii emocji. „Przegląd Socjologii Jakościowej”, t. 9, nr 2, s. 6-9.

Lakoff George, Johnson Mark (2010) Metafory w naszym życiu. Przełożył Tomasz Krzeszowski. Warszawa: Wydawnictwo Aletheia.

Leszczyńska Katarzyna, Skowronek Katarzyna (2010) Socjologia jezyka / socjolingwistyka a społeczna analiza dyskursu. Perspektywa socjologa i językoznawcy. „,Socjolingwistyka”, t. 24, s. 7-28.

Mamzer Hanna (2015) Posthumanizm we wspótczesnych modelach rodzin: zwierzęta jako członkowie rodziny? [w:] Stella Grotowska, Iwona Taranowicz, red., Rodzina wobec wyzwań wspótczesności. Wybrane problemy. Wrocław: Oficyna Wydawnicza Arboretum, s. $151-176$.

Mamzer Hanna (2017) Oczekiwania wobec lekarzy weterynarii jako odzwierciedlenie przemian świadomości ludzi. „Życie weterynaryjne", t. 92, nr 6, s. 415-419.

Marciniak Łukasz (2008) Stawanie się nauczycielem akademickim. Analiza symboliczno-interakcjonistyczna. „Przegląd Socjologii Jakościowej", t. 4, nr 2.

Mason Gloria, Littin Kate (2003) The humanness of rodent pest control. „Animal Welfare”, vol. 12, no. 1, s. 1-37.
Miller Piotr (2010) Konstruowanie tożsamości ratownika górskiego. Analiza symboliczno-interakcjonistyczna. „Przegląd Socjologii Jakościowej", t. 6, nr 1.

Pawliszak Piotr, Rancew-Sikora Dorota (2012) Wprowadzenie do socjologicznej analizy dyskursu(SAD). „Studia Socjologiczne”, t. 1(204), s. 5-18.

Peggs Kay (2012) Animals and sociology. London: Palgrave Macmillan.

Piłat-Borcuch Magdalena (2013) Między tożsamością osobowa a postawa społeczna. "Zeszyty Naukowe Politechniki Śląskiej, Seria: Organizacja i zarządzanie", t. 65/1897, s. 317-327.

Scott Marvin, Lyman Stanford (1968) Accounts. „American Sociological Review", vol. 33, no. 1. s. 46-62.

Simlat-Żuk Beata (2012) Emocje jako przedmiot badań socjologicznych [w:] Agnieszka Figiel, Łukasz Rogowski, red., W tym szaleństwie jest metoda. Jak można badać społeczeństwo? Poznań: Wydawnictwo Naukowe Wydziału Nauk Społecznych.

Słowińska Karolina (2010) Społeczny świat hodowców gołębi pocztowych. „Przegląd Socjologii Jakościowej”, t. 6, nr 3.

Strauss Anselm (2013) Zwierciadła i maski. W poszukiwaniu tożsamości. Przełożyła Agnieszka Hałas. Kraków: Zakład Wydawniczy Nomos.

Sullivan Robert (2005) Rats. Observations on the history and habitat of the city's most unwanted inhabitants. New York, London: Bloomsbury.

Sykes Gresham, Matza David (1957) Techniques of neutralization: A theory of delinquency. "American Sociological Review", vol. 22, no. 6, s. 664-670.

Zerubavel Eviatar (2006) The elephant in the room. Silence and denial in everyday life. Oxford, New York: Oxford University Press.

\section{Cytowanie}

Jarzębowska Gabriela (2020) „Płatni mordercy”? Dyskurs budowania tożsamości zawodowej wśród pracowników deratyzacji. „Przegląd Socjologii Jakościowej", t. 16, nr 4, s. 192-209 [dostęp dzień, miesiąc, rok]. Dostępny w Internecie: «www.przegladsocjologiijakosciowej.org). DOI: http://dx.doi.org/10.18778/1733-8069.16.4.10 


\title{
"Hitmen"? The Discourse of Developing the Professional Identity Among Rat Exterminators
}

\begin{abstract}
This article analyzes the discursive practices that shape rat exterminators' professional identity. Interviews with pest control professionals (PCPs) reveal the rhetorics of hard work on their identity. My main thesis is that the shaping of this identity is performed on two levels. The first one (social) is about identity shaped in opposition to the perceived negative social reception of this profession. The second one (personal)is about internal work based on struggling with the ethical challenges connected with the professional duties. Based on the conducted interviews, I have recognized four strategies of the rationalization of exterminating animals. The above-mentioned two levels of identity work have the common, namely the belief in the social usefulness of working in pest control.
\end{abstract}

Keywords: rats, pest control, professional identity, discourse analysis, ethics 